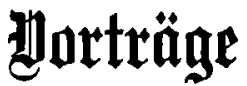

\section{der theologildan}

sebalten am 31. Mlat 1888.

$$
\text { (IV. Folge.) }
$$

Direttor Dr. Sadj/ge (F̧erborn) :

über bie Midglidfeit, (Sott ju erfennent.



Giefsicn,

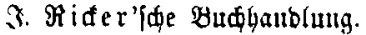
1888. 
